Article

\title{
Doing More on the Corporate Sustainability Front: A Longitudinal Analysis of CSR Reporting of Global Fashion Companies
}

\author{
Penglan Feng ${ }^{\dagger}$ and Cindy Sing-bik Ngai $*,+$ \\ Department of Chinese and Bilingual Studies, The Hong Kong Polytechnic University, Hung Hom, Kowloon, \\ Hong Kong SAR, HK 999077, China; diane.feng@connect.polyu.hk \\ * Correspondence: cindy.sb.ngai@polyu.edu.hk \\ + The authors are contributed equally to the study.
}

Received: 23 February 2020; Accepted: 18 March 2020; Published: 21 March 2020

check for updates

\begin{abstract}
The fashion industry has been under the spotlight in recent years due to its negative social and environmental impacts. However, there is limited literature on how companies in the fashion industry communicate their corporate social responsibility (CSR) practices. This study aims to present a full picture of the paradigm of CSR reporting in the fashion industry by revealing the changes in CSR reporting practices and identifying the possible reasons behind the change. Content analysis was employed to investigate 12 global fashion companies' 43 CSR reports from 2013 to 2016. Findings showed that more comprehensive CSR reporting was practiced in the fashion industry to meet stakeholders' expectations. The reporting of 16 CSR issues experienced a rise. Labor and environmental issues were predominant in the reports while more attention was given to human rights, human development and training, and sustainable resource use. A growing use of a proactive approach in reporting environmental issues was also witnessed. This study is the first to offer insights into how global fashion corporations communicate their CSR practices via CSR reports and provides useful information about CSR strategies, practices and reporting in the fashion industry.
\end{abstract}

Keywords: corporate social responsibility; fashion industry; labor issues; environmental issues; CSR reports; longitudinal study

\section{Introduction}

The economic development in the 19th and 20th centuries has resulted in a globally interconnected society [1]. This has enabled a shift of garment manufacturing to countries with low labor costs [2,3]. However, the heavy pollution caused in the whole lifecycle of fashion, such as the growing use of raw materials, dyeing, transporting, and disposing of used clothes, has severely impacted the environment [4-6]. In 1999, Gap Inc. was condemned for violating Saipan's federal law due to the poor working conditions and overtime work, and, in 2000, it was accused of exploiting child labor in Cambodia [7]. In 2013, the Rana Plaza, the world's largest garment factory in Bangladesh, collapsed, causing approximately 2500 injuries and over 1000 fatalities due to the appalling working conditions [8]. In 2018, fast-fashion brand H\&M, which claims to have been recycling old clothes for years, was exposed for burning 12 metric tons of unsold inventories annually.

Given the negative social and environment impacts of the fashion industry, governments and international organizations have been closely monitoring garment manufacturers worldwide [9]. According to Chen and Burns [4], the increased awareness and concern among stakeholders has prompted the fashion industry to alleviate the environmental and social impacts of its manufacturing processes. To reduce the negative effects of garment production throughout its lifecycle, fashion 
companies have developed additional corporate social responsibility (CSR) principles and activities [2,5]. However, adopting CSR does not only consist of CSR effort but how companies present these activities to the public and investors $[10,11]$. In fact, sustainability reporting is regarded as a core element in CSR practices and management [12].

To date, only a few studies have directly examined sustainability reporting in the fashion industry, an industry that faces many CSR challenges. These studies mainly relied on cross-sectional analyses from certain regions and lacked longitudinal analysis. This study, therefore, aims to contribute to understanding the interaction of leading fashion companies with the larger global policy agenda of sustainability by investigating sustainability reports of leading apparel companies from 2013 to 2016, to reveal the changes in CSR reporting practices and identify the possible reasons behind the change so as to provide valuable insights into CSR strategies, practices and reporting for practitioners in the apparel industry.

\section{Theoretical Background}

\subsection{CSR Challenges in the Fashion Industry}

Corporate Social Responsibility (CSR) has different definitions and is closely associated with the concept of corporate sustainability [13]. Corporate sustainability is a policy framework that addresses and implements a high-level UN development policy while CSR is "best understood as an emerging global legal norm focused on businesses, encompassing social and environmental obligations, drawn from the international soft law instruments" [14]. In other words, CSR refers to the self-regulatory act performed by international business to mitigate the negative economic, environmental, and social impacts on society $[14,15]$. These self-regulatory CSR policies and practices are implemented in the CSR framework developed, based on international norms and standards [16].

Today's fashion world has been experiencing rapid changes, which are characterized by high volatility, low predictability, a short product lifecycle, and high volume of impulse purchasing [17]. To maximize profit margin, the fashion industry outsources production to developing countries $[9,18]$, raising concerns about the working conditions of employees [19] and the use of chemicals in manufacturers' countries [20]. The volume of clothing consumption and used garments' disposal can lead to sustainability problems, possibly positioning the fashion industry as an important contributor to global environmental and social issues [5,20]. In a survey on social responsibility distributed to 74 members of the International Textile and Fashion Association, the respondents generally agreed that working conditions, child labor, consumerism, and environmental degradation are important CSR issues to be addressed [21]. Labor and environmental issues are indeed the most significant sustainability issues in the clothing industry, and therefore, require further investigation.

\subsection{CSR Related to Environmental Issues}

According to the Nordic Fashion Association [22], the fashion industry is one of the most polluting industries globally. A recent study [5] has confirmed that the lifecycle of fashion reflects a perspective of the extended producer. The raw materials, fabrics, textile processing, manufacturing, distribution, and ultimately, disposal could all exert a negative impact on the environment $[5,9]$. The heavy pollution caused by the overuse of herbicides and pesticides during the growth of conventional cotton poses threats to the environment and human health worldwide [4]. Manufacturing processes, such as dyeing, printing, tanning, and finishing, require a considerable amount of chemical substances, leading to environmental issues $[4,23]$. The rising frequency of transporting raw materials and finished products in and out of different regions and countries also raises the greenhouse gas emissions [6,24].

Therefore, fashion companies are now paying more attention to the environmental impacts caused [9]. Some firms have begun to include environmental sustainability initiatives in their business strategies and production process to mitigate climate change and safeguard natural resources [25]. A study [26] highlighted that sustainable development has been focused on in production processes, such as how to properly manage water, waste and sustainable resources, and the implementation of a 
full environmental management system that monitors and evaluates pollution, and the lifecycle in the manufacturing process. In the product lifecycle management, fashion firms have the most direct impact on garment manufacturing, distribution, and retail [5]. However, this impact does not mean that their responsibility should be limited to the stages of product lifecycle because consumers can also make environmentally responsible decisions during product usage [4]. As such, corporations could educate consumers about how to be environmentally-friendly when consuming final products. For example, Nudie and Levi's encouraged their customers to avoid laundering jeans for the first six months to create personalized, unique wear and help reduce water and detergent consumption [5].

\subsection{CSR Related to Labor Issues}

The fashion industry is closely tied to labor issues due to its labor-intensive nature [27]. Since the manufacturing process in this sector does not require a high level of skills, the field labor is flooded with young, poorly educated people who can easily be replaced; they are more likely to be exposed to poor working conditions and are paid low wages [24,27]. Labor issues, such as the abuse of political and economic rights, unsafe working conditions, child labor, low wages, long working hours, and health and safety issues, are the main problems seen in outsourcing nations [28]. Suppliers who are pressured by tight deadlines may force garment workers to work overtime at the expense of their own well-being [29-31]. Therefore, the implementation of CSR might be adversely affected. Another concern is that poor working conditions and the employment of child labor would take place when the managers are unaware of these issues in outsourcing countries [18].

Scandals concerning the violation of labor rights and the mistreatment of workers have prompted numerous multinational enterprises (MNEs) to adopt various Codes of Conduct (CoC), promoting social sustainability in the supply chain and a baseline of expected standards [32]. To date, major fashion brands in America and the U.K., as well as fast-fashion companies, have committed themselves to meeting ethical sourcing codes. A total of 12 U.S.-based fashion companies have joined the Fair Labor Association and are committed to following an industry-wide Code of Conduct that allows external monitoring of compliance. The Ethical Trading Initiative that promotes the effective implementation of the Labor Rights' Code of Conduct has 22 members in the U.K.; over one-fourth of them are clothing and footwear companies [33].

\subsection{CSR Reporting in the Fashion Industry}

Implementing CSR does not solely involve CSR effort, as how companies present their CSR policies and practices to stakeholders is also important $[10,11]$. Previous research has found that CSR can help a company attract new business and customers, thus gaining an advantage over its competitors $[1,34]$. CSR also effectively helps a company build its reputation [33] by promoting stakeholders' positive evaluations of the firm [16,35], as well as enhances staff retention and motivation [18,34,36], contributing to business success and sustainable development [3,37]. Various channels, such as press releases, corporate websites and sustainability reports, are used by companies to share CSR practices and express goodwill to stakeholders [5,38].

Despite the importance of CSR communication, only a few studies have explored CSR communication in the fashion industry. Woo and Jin [38] compared the CSR communication practices on the websites of six fashion firms from different countries. In another study of CSR communication among fashion retailers, the researchers investigated the CSR practices of 17 leading fashion retailers in the U.S. on their corporate websites for two consecutive years [39]. A recent study identified the environmental and social sustainability practices adopted by Italian fashion companies and how they communicated their sustainability commitment via their corporate websites [12]. Although these studies have provided some insights into CSR communication in the fashion industry through corporate websites, they did not reveal the full picture of CSR communication in the industry since they focused on examining information from company websites. Websites allow companies to publicize information to different stakeholders in a prompt manner [12,39], but only selected CSR information is included 
on corporate websites because the stakeholders may find reading excessive information placed on websites difficult. When compared with webpages, a sustainability report is more comprehensive because it includes information about all business operations and informs stakeholders fully about the organization's major impacts on society and the environment [37] in print or e-book format. In addition, the previous studies have failed to provide a global view as they were often based on specific regions or country-specific. Only one study attempted to investigate the change of CSR practices over time but the time period of the study was limited to two consecutive years. To provide a comprehensive view on CSR communication in the fashion industry, we examine leading fashion companies across the globe by analyzing their sustainability reports for four consecutive years.

\subsection{Purpose of Study and Research Questions}

This study aims to understand the development of CSR practices and reporting in the fashion industry through conducting a longitudinal study. Although previous research has suggested that the fashion industry focused its CSR efforts on labor and environmental issues, we aim to investigate if other CSR-related issues are also included in the industry's sustainability reports. We expect that the CSR practices addressed by fashion corporations in their sustainability reports will change over time. Hence, the first set of research questions is proposed:

RQ1a. What are the themes and subthemes of CSR practices communicated in the sustainability reports of global fashion companies?

RQ1b. Are there any changes in CSR communication over time?

Given the importance of environmental and labor issues in the fashion industry, further investigation into how CSR practices communicated through the sustainability reports in these two prominent domains is also needed, and as a result, the following two sets of research questions are derived:

RQ2a. What are the key labor issues communicated in the sustainability reports of global fashion companies?

$\mathrm{RQ} 2 \mathrm{~b}$. Are there any changes in the practices over time?

RQ3a. What are the key environmental issues communicated in the sustainability reports of global fashion companies?

RQ3b. Are there any changes in the practices over time?

Lastly, previous research on CSR communication via the investigation of corporate websites has suggested that environmental initiatives were given less importance when compared with labor issues [39]. Therefore, this leads us to the following research question:

RQ4. Does the CSR reporting of fashion companies place more emphasis on labor issues than environmental issues?

\section{Materials and Methods}

\section{Firm Selection}

We identified the apparel firms by adopting the list of Top Global 250 retailers published in Stores magazine in 2017 as the sampling frame. There were 45 out of 250 global retailers (18\%) belonging to the categories of apparel and accessories with nearly one-third of them having expanded internationally. We defined fashion companies as those that do not only sell but also design and manufacture clothes. Therefore, department and discount stores, which only sell clothes and do not own factories or outsource any garment production, were excluded. Second, we examined CSR communication via official sustainability reports. Hence, firms that did not publish their sustainability reports or made them available on open platforms, including company official websites, GRI database, annual reports, and websites of related stock markets, were excluded. In addition to this, we examined reports written in English only because 
English is the lingua franca of the sustainability reports of global fashion companies. Lastly, companies which had published brief or incomplete sustainability reports were excluded. In total, 12 out of $45(27 \%)$ global apparel companies, namely The TJX Companies, Inc., LVMH Moet Hennessy, Inditex, S.A., H\&M Hennes \& Mauritz, AB, The Gap, Inc., Fast Retailing Co., Ltd, Kering S.A., Next plc, Hermes International SCA, Ralph Lauren Corporation, Coach, Inc., and American Eagle Outfitters, Inc. were included in the analysis (see Table 1 for the companies' country of origin and retail revenue).

Table 1. Profile of the selected fashion companies $(N=12)$.

\begin{tabular}{cccc}
\hline Company Name & Country of Origin & $\begin{array}{c}\text { FY2015 Retail Revenue } \\
\text { (Million USD) }\end{array}$ & Company Code \\
\hline The TJX Companies, Inc. & America & 30,945 & $\mathrm{~A}$ \\
LVMH Moet Hennessy & France & 25,605 & $\mathrm{~B}$ \\
Inditex, S.A. & Spain & 23,074 & $\mathrm{C}$ \\
H\&M Hennes \& Mauritz AB & Sweden & 21,678 & $\mathrm{D}$ \\
The Gap, Inc. & America & 15,797 & $\mathrm{E}$ \\
Fast Retailing Co., Ltd. & Japan & 14,239 & $\mathrm{~F}$ \\
Kering S.A. & France & 7039 & $\mathrm{G}$ \\
Next plc & The UK & 6339 & $\mathrm{H}$ \\
Hermes International SCA & France & 4310 & $\mathrm{I}$ \\
Ralph Lauren Corporation & America & 3933 & $\mathrm{~J}$ \\
Coach, Inc. & America & 3760 & $\mathrm{~K}$ \\
American Eagle Outfitters, Inc. & America & 3522 & $\mathrm{~L}$ \\
\hline
\end{tabular}

\section{Data Collection}

The sustainability reports of each firm were collected from company websites, GRI database, annual reports, or related stock markets. Since some companies' 2017 CSR reports had not been released when we collected the data, we decided to include the available reports of the 12 companies from 2013 to 2016 to examine how the largest fashion companies reported their sustainability practices. Furthermore, different companies have different ways of naming their sustainability reports such as corporate sustainability report, CSR report and citizenship report. Based on this, we regarded all reports that aimed at communicating the social and environmental sustainability actions of a company as sustainability reports in our study. A total of 43 sustainability reports from 12 companies were collected for analysis, with the number of pages ranging from 15 to 204. The lengthy reports resulted from the biennial reporting practice of some companies.

\section{Research Method}

Content analysis was employed in this study. Content analysis is a widely used method when researching available documents from companies, especially those about sustainability information $[40,41]$. Previous studies have used this method when reviewing documents and other available information, such as corporate websites, to collect a large data pool and enable comparative analysis [36,38,39]. This choice of approach also follows previous CSR communication studies that explored similar topics in the fashion industry [24,42].

Applying content analysis to sustainability reports requires a structured coding scheme $[38,39]$. Although a wide variety of CSR reporting frameworks including SA8000, ISO 14000, Global Reporting Initiative (GRI) and ISO 26000 are adopted by global fashion companies, recent research on CSR evaluation criteria [43] suggested that ISO 26000 is one of the most comprehensive frameworks that covers corporate governance, human rights, environment, stakeholders, diversity of organizational policy and different economic conditions. Given the comprehensive nature of ISO 26000, we developed our coding scheme based on the seven core themes and subthemes included in the 2010 version of ISO 26000: organizational governance (OG), human rights (HR), labor practices (LP), environment (EN), fair operating practices (FO), consumer issues (CO), and community involvement and development (CID) [44]. For example, OG refers to the practice of accountability and transparency, and leadership in creating an organizational culture that considers the core values of social responsibility when making business decisions. HR refers 
to treating all individuals with respect and making special efforts to help vulnerable groups [44] (see Table 2 for the core CSR themes and subthemes adopted from ISO 26000 in this study). 
Table 2. Core CSR themes and subthemes adopted from ISO 26000.

\begin{tabular}{|c|c|c|c|c|c|c|c|}
\hline Core Themes & $\begin{array}{c}\text { Organizational } \\
\text { Governance (OG) }\end{array}$ & Human Rights (HR) & Labor Practice (LP) & The Environment (EN) & $\begin{array}{l}\text { Fair Operating Practices } \\
\text { (FOP) }\end{array}$ & Consumer Issues (CI) & $\begin{array}{l}\text { Community Involvement } \\
\text { and Development (CID) }\end{array}$ \\
\hline Sub-themes & N/A & $\begin{array}{l}\text { Due diligence (DD) } \\
\text { Human rights risk } \\
\text { situations (HRRS) } \\
\text { Avoidance of complicity } \\
\text { (AoC) } \\
\text { Discrimination and } \\
\text { vulnerable groups (DVG) } \\
\text { Civil and political rights } \\
\text { (CPR) } \\
\text { Economic, social and } \\
\text { cultural rights (ESCR) } \\
\text { Resolving grievances (RG) } \\
\text { Fundamental principles and } \\
\text { rights at work (FPR) }\end{array}$ & $\begin{array}{c}\text { Employment and } \\
\text { employment relationships } \\
\text { (EER) } \\
\text { Conditions of work and } \\
\text { social protection (CWSP) } \\
\text { Social dialogue (SD) } \\
\text { Health and safety at work } \\
\text { (HS) } \\
\text { Human development and } \\
\text { training in the workplace } \\
\text { (HDT) }\end{array}$ & $\begin{array}{l}\text { Prevention of pollution (PP) } \\
\text { Sustainable resource use } \\
\text { (SRU) } \\
\text { Climate change mitigation } \\
\text { and adaptation (CCMA) } \\
\text { Protection of the } \\
\text { environment, biodiversity } \\
\text { and restoration of natural } \\
\text { habitats (PEBNH) }\end{array}$ & $\begin{array}{c}\text { Anti-corruption (AC) } \\
\text { Responsible political } \\
\text { involvement (RPI) } \\
\text { Fair competition (FC) } \\
\text { Promoting social } \\
\text { responsibility in the value } \\
\text { chain (PSR) } \\
\text { Respect for property rights } \\
\text { (RPR) }\end{array}$ & $\begin{array}{c}\text { Fair marketing, factual and } \\
\text { unbiased information and } \\
\text { fair contractual practices } \\
\text { (FMCP) } \\
\text { Protecting consumers' } \\
\text { health and safety (PCHS) } \\
\text { Sustainable consumption } \\
\text { (SC) } \\
\text { Consumer service, support, } \\
\text { and complaint and dispute } \\
\text { resolution (CSS) } \\
\text { Consumer data protection } \\
\text { and privacy (CDPP) } \\
\text { Access to essential services } \\
\text { (AES) } \\
\text { Education and awareness } \\
\text { (EA) }\end{array}$ & $\begin{array}{l}\text { Community involvement } \\
\text { (CI) } \\
\text { Education and culture (EC) } \\
\text { Employment creation and } \\
\text { skills development (ECSD) } \\
\text { Technology development } \\
\text { and access (TDA) } \\
\text { Wealth and income creation } \\
\text { (WIC) } \\
\text { Health (HE) } \\
\text { Social investment (SI) }\end{array}$ \\
\hline
\end{tabular}


To answer RQ1 to RQ3, we employed the "presence or absence" technique in the coding process. If the CSR information was disclosed in a report, we coded " 1 "; otherwise, we coded "0". Double coding was allowed if an activity fitted into more than one category.

We believed that the amount of information discussed intensively in each disclosure could reflect what the company valued the most. Therefore, we coded "intensity" by counting the total number of keywords in each disclosure, especially in the major themes related to labor practices and environmental issues. For instance, "prevention of pollution" was a key issue under "the environment" theme in the coding frame. When we coded the intensity of this category, we counted pollution-related keywords and their word classes, such as pollution, polluted, pollutants, and polluting in the text. Those keywords appearing in tables, charts, and footnotes were excluded. We only counted full names and abbreviations once when they showed up simultaneously. For example, in "electricity and fuels used to operate our stores generate the majority of the greenhouse gas (GHG) emissions we can control directly," greenhouse gas emissions and GHG were not counted twice.

For companies that published biennial reports instead of annual reports, we coded the keywords based on the indicated year. If the disclosure did not include a specific time or date, we coded it in each year of the reporting period.

To ensure coding reliability, an author and a trained coder co-coded two companies' reports (15\% of the reports) for inter-rater checking. Table 3 shows the inter-rater checking results of two companies' reports by year. Overall, the percentage of agreement was above $91.3 \%$. The values of Cohen's Kappa were above 0.85 and those of Krippendorff's Alpha were above 0.851 . Appendix 2 displays the results of inter-rater reliability.

Table 3. Inter-rater reliability checks.

\begin{tabular}{ccccc}
\hline Variables & Percent of Agreement & Cohen's Kappa & Krippendorff's Alpha & N \\
\hline 2016 of company E & $97.80 \%$ & 0.96 & 0.96 & 46 \\
2015 of company E & $97.80 \%$ & 0.961 & 0.962 & 46 \\
2014 of company E & $91.30 \%$ & 0.85 & 0.851 & 46 \\
2013 of company E & $91.30 \%$ & 0.85 & 0.851 & 46 \\
2016 of company F & $93.50 \%$ & 0.899 & 0.9 & 46 \\
2015 of company F & $95.70 \%$ & 0.933 & 0.934 & 46 \\
2014 of company F & $97.80 \%$ & 0.967 & 0.967 & 46 \\
2013 of company F & $97.80 \%$ & 0.967 & 0.967 & 46 \\
\hline
\end{tabular}

\section{Statistical Analyses}

To examine the research questions, we used both descriptive statistics (RQ1-3) and inferential statistics (RQ4) (i.e., independent sampled two-tailed t-test) to reveal the CSR reporting practices and the changes in practices over time in the apparel industry, as well as undertook a comparison of the communication practices of American and European firms.

For RQ1, we analyzed the data by adopting the number of companies as the measuring unit. To examine RQ2 and RQ3, we incorporated the observed intensity for the issues of Labor Practice and the Environment by counting the total number of key words in each disclosure in our analysis.

\section{Findings}

\subsection{Comprehensive Reporting of All CSR Themes}

We inquired into the themes of CSR practices communicated in the sustainability reports of global fashion companies and the changes in practices over time for RQ1a and b. Table 4 shows that, as of 2016, all themes and subthemes of ISO 26000 except "Fair competition" were addressed in the sustainability reports of 12 global fashion companies. 
Table 4. The frequency and percentage of companies reporting CSR themes $(N=12)$.

\begin{tabular}{|c|c|c|c|c|c|c|c|c|c|c|c|c|}
\hline \multirow{2}{*}{ Themes } & \multirow{2}{*}{$\begin{array}{l}\text { Subthemes } \\
\text { G }\end{array}$} & \multicolumn{2}{|c|}{$\begin{array}{c}2013 \\
(N / \%)\end{array}$} & \multicolumn{2}{|c|}{$\begin{array}{c}2014 \\
(N / \%)\end{array}$} & \multicolumn{2}{|c|}{$\begin{array}{c}2015 \\
(N / \%)\end{array}$} & \multicolumn{2}{|c|}{$\begin{array}{c}2016 \\
(N / \%)\end{array}$} & \multirow{2}{*}{$\begin{array}{c}\mathbf{M} \\
100 \%\end{array}$} & \multirow{2}{*}{$\begin{array}{l}\text { SD } \\
0 \%\end{array}$} & \multirow{2}{*}{$\begin{array}{c}\begin{array}{c}\text { Average Annual } \\
\text { Growth Rate }\end{array} \\
0 \%\end{array}$} \\
\hline & & 12 & $100 \%$ & 12 & $100 \%$ & 12 & $100 \%$ & 12 & $100 \%$ & & & \\
\hline \multirow{8}{*}{ HR } & $\mathrm{DD}$ & 4 & $33 \%$ & 4 & $33 \%$ & 5 & $42 \%$ & 7 & $58 \%$ & $42 \%$ & $12 \%$ & $22 \%$ \\
\hline & HRRS & 2 & $17 \%$ & 2 & $17 \%$ & 2 & $17 \%$ & 2 & $17 \%$ & $17 \%$ & $0 \%$ & $0 \%$ \\
\hline & $\mathrm{AoC}$ & 11 & $92 \%$ & 12 & $100 \%$ & 11 & $92 \%$ & 11 & $92 \%$ & $94 \%$ & $4 \%$ & $0 \%$ \\
\hline & RG & 3 & $25 \%$ & 6 & $50 \%$ & 5 & $42 \%$ & 7 & $58 \%$ & $44 \%$ & $14 \%$ & $41 \%$ \\
\hline & DVG & 11 & $92 \%$ & 10 & $83 \%$ & 11 & $92 \%$ & 12 & $100 \%$ & $92 \%$ & $7 \%$ & $3 \%$ \\
\hline & CPR & 9 & $75 \%$ & 10 & $83 \%$ & 9 & $75 \%$ & 9 & $75 \%$ & $77 \%$ & $4 \%$ & $0 \%$ \\
\hline & ESCR & 11 & $92 \%$ & 11 & $92 \%$ & 10 & $83 \%$ & 11 & $92 \%$ & $90 \%$ & $4 \%$ & $0 \%$ \\
\hline & FPR & 12 & $100 \%$ & 11 & $92 \%$ & 11 & $92 \%$ & 11 & $92 \%$ & $94 \%$ & $4 \%$ & $-3 \%$ \\
\hline \multirow{5}{*}{ LP } & EER & 12 & $100 \%$ & 11 & $92 \%$ & 11 & $92 \%$ & 11 & $92 \%$ & $94 \%$ & $4 \%$ & $-3 \%$ \\
\hline & CWSP & 12 & $100 \%$ & 12 & $100 \%$ & 12 & $100 \%$ & 12 & $100 \%$ & $100 \%$ & $0 \%$ & $0 \%$ \\
\hline & SD & 9 & $75 \%$ & 8 & $67 \%$ & 9 & $75 \%$ & 10 & $83 \%$ & $75 \%$ & $7 \%$ & $4 \%$ \\
\hline & HS & 12 & $100 \%$ & 12 & $100 \%$ & 12 & $100 \%$ & 12 & $100 \%$ & $100 \%$ & $0 \%$ & $0 \%$ \\
\hline & HDT & 12 & $100 \%$ & 12 & $100 \%$ & 12 & $100 \%$ & 12 & $100 \%$ & $100 \%$ & $0 \%$ & $0 \%$ \\
\hline \multirow{4}{*}{ EN } & PP & 8 & $67 \%$ & 8 & $67 \%$ & 6 & $50 \%$ & 6 & $50 \%$ & $58 \%$ & $10 \%$ & $-8 \%$ \\
\hline & SRU & 11 & $92 \%$ & 11 & $92 \%$ & 11 & $92 \%$ & 11 & $92 \%$ & $92 \%$ & $0 \%$ & $0 \%$ \\
\hline & CCMA & 11 & $92 \%$ & 11 & $92 \%$ & 11 & $92 \%$ & 11 & $92 \%$ & $92 \%$ & $0 \%$ & $0 \%$ \\
\hline & PEBNH & 9 & $75 \%$ & 11 & $92 \%$ & 11 & $92 \%$ & 12 & $100 \%$ & $90 \%$ & $10 \%$ & $10 \%$ \\
\hline \multirow{5}{*}{ FOP } & $\mathrm{AC}$ & 7 & $58 \%$ & 9 & $75 \%$ & 10 & $83 \%$ & 10 & $83 \%$ & $75 \%$ & $12 \%$ & $13 \%$ \\
\hline & PRI & 2 & $17 \%$ & 2 & $17 \%$ & 1 & $8 \%$ & 2 & $17 \%$ & $15 \%$ & $4 \%$ & $0 \%$ \\
\hline & $\mathrm{FC}$ & 0 & $0 \%$ & 0 & $0 \%$ & 0 & $0 \%$ & 0 & $0 \%$ & $0 \%$ & $0 \%$ & $0 \%$ \\
\hline & PSR & 11 & $92 \%$ & 12 & $100 \%$ & 12 & $100 \%$ & 12 & $100 \%$ & $98 \%$ & $4 \%$ & $3 \%$ \\
\hline & RPR & 2 & $17 \%$ & 2 & $17 \%$ & 3 & $25 \%$ & 3 & $25 \%$ & $21 \%$ & $4 \%$ & $17 \%$ \\
\hline \multirow{7}{*}{ CI } & FMCP & 2 & $17 \%$ & 2 & $17 \%$ & 1 & $8 \%$ & 2 & $17 \%$ & $15 \%$ & $4 \%$ & $17 \%$ \\
\hline & PCHS & 7 & $58 \%$ & 7 & $58 \%$ & 9 & $75 \%$ & 9 & $75 \%$ & $62 \%$ & $10 \%$ & $10 \%$ \\
\hline & SC & 4 & $33 \%$ & 7 & $58 \%$ & 7 & $58 \%$ & 8 & $67 \%$ & $54 \%$ & $14 \%$ & $30 \%$ \\
\hline & CSS & 11 & $92 \%$ & 11 & $92 \%$ & 12 & $100 \%$ & 12 & $100 \%$ & $94 \%$ & $4 \%$ & $0 \%$ \\
\hline & CDPP & 1 & $8 \%$ & 2 & $17 \%$ & 2 & $17 \%$ & 3 & $25 \%$ & $17 \%$ & $7 \%$ & $50 \%$ \\
\hline & AES & 9 & $75 \%$ & 9 & $75 \%$ & 9 & $75 \%$ & 9 & $75 \%$ & $75 \%$ & $0 \%$ & $0 \%$ \\
\hline & EA & 1 & $8 \%$ & 1 & $8 \%$ & 1 & $8 \%$ & 1 & $8 \%$ & $8 \%$ & $0 \%$ & $0 \%$ \\
\hline \multirow{7}{*}{ CID } & CIV & 12 & $100 \%$ & 12 & $100 \%$ & 12 & $100 \%$ & 12 & $100 \%$ & $100 \%$ & $0 \%$ & $0 \%$ \\
\hline & EC & 11 & $92 \%$ & 11 & $92 \%$ & 10 & $83 \%$ & 11 & $92 \%$ & $90 \%$ & $4 \%$ & $0 \%$ \\
\hline & ECSD & 10 & $83 \%$ & 11 & $92 \%$ & 11 & $92 \%$ & 9 & $75 \%$ & $85 \%$ & $8 \%$ & $-3 \%$ \\
\hline & TDA & 0 & $0 \%$ & 0 & $0 \%$ & 1 & $8 \%$ & 2 & $17 \%$ & $6 \%$ & $8 \%$ & $33 \%$ \\
\hline & WIC & 6 & $50 \%$ & 5 & $42 \%$ & 4 & $33 \%$ & 6 & $50 \%$ & $44 \%$ & $\%$ & $4 \%$ \\
\hline & HE & 9 & $75 \%$ & 9 & $75 \%$ & 10 & $83 \%$ & 10 & $83 \%$ & $79 \%$ & $5 \%$ & $4 \%$ \\
\hline & SI & 10 & $83 \%$ & 11 & $92 \%$ & 11 & $92 \%$ & 11 & $92 \%$ & $90 \%$ & $4 \%$ & $3 \%$ \\
\hline
\end{tabular}

Remark: percentage is rounded up to a whole number.

"Fundamental principles and rights at work" $\left(\mathrm{M}_{2013-2016}=94 \%, \mathrm{SD}=4 \%\right)$ and "Avoidance of complicity" ( $\left.\mathrm{M}_{2013-2016}=94 \%, \mathrm{SD}=4 \%\right)$ were two of the most frequently addressed HR subthemes, followed by "Discrimination and vulnerable groups" ( $\mathrm{M}_{2013-2016}=92 \%, \mathrm{SD}=7 \%$ ), "Economic, social and cultural rights" $\left(\mathrm{M}_{2013-2016}=90 \%, \mathrm{SD}=4 \%\right)$, "Civil and political rights" $\left(\mathrm{M}_{2013-2016}=77 \%, \mathrm{SD}=\right.$ $4 \%)$, “Resolving grievances" $\left(\mathrm{M}_{2013-2016}=44 \%, \mathrm{SD}=14 \%\right)$, and “Due diligence" $\left(\mathrm{M}_{2013-2016}=42 \%\right.$, $\mathrm{SD}=12 \%)$. On the other hand, "Human risk situation" $\left(\mathrm{M}_{2013-2016}=17 \%, \mathrm{SD}=0 \%\right)$ was the least reported subtheme.

All LP subthemes were included in our sample. The most reported subtheme was "Human development and training in the workplace" $\left(\mathrm{M}_{2013-2016}=100 \%, \mathrm{SD}=0 \%\right)$, "Conditions of work and 
social protection" $\left(\mathrm{M}_{2013-2016}=100 \%, \mathrm{SD}=0 \%\right)$ and "Health and safety at work" $\left(\mathrm{M}_{2013-2016}=100 \%\right.$, $\mathrm{SD}=0 \%)$, followed by "Employment and employment relationships" $\left(\mathrm{M}_{2013-2016}=94 \%, \mathrm{SD}=4 \%\right)$. The least addressed issue was "social dialogue" $\left(\mathrm{M}_{2013-2016}=75 \%\right.$, $\left.\mathrm{SD}=6 \%\right)$.

For EN, "Sustainable resource use" $\left(\mathrm{M}_{2013-2016}=92 \%, \mathrm{SD}=0 \%\right)$ and "Climate change mitigation and adaptation" $\left(\mathrm{M}_{2013-2016}=92 \%, \mathrm{SD}=0 \%\right)$ topped the CSR reporting list. "Protection of the environment, biodiversity, and restoration of natural habitats" $\left(\mathrm{M}_{2013-2016}=90 \%, \mathrm{SD}=10 \%\right)$ ranked second while "Prevention of pollution" ( $\left.\mathrm{M}_{2013-2016}=58 \%, \mathrm{SD}=10 \%\right)$ came last.

FOP was the least reported theme in the sustainability reports. Of all the subthemes, "Promoting social responsibility in the value chain" $\left(\mathrm{M}_{2013-2016}=98 \%, \mathrm{SD}=4 \%\right)$ was the most frequently reported followed by "Anti-corruption" $\left(\mathrm{M}_{2013-2016}=75 \%\right.$, $\left.\mathrm{SD}=12 \%\right)$. The remaining two subthemes: "Respect for property rights" $\left(\mathrm{M}_{2013-2016}=21 \%, \mathrm{SD}=5 \%\right)$ and "Responsible political involvement" $\left(\mathrm{M}_{2013-2016}\right.$ $=15 \%, \mathrm{SD}=4 \%$ ) were rarely addressed.

The subtheme of "Consumer service, support, and complaint and dispute resolution" $\left(\mathrm{M}_{2013-2016}\right.$ $=94 \%, \mathrm{SD}=4 \%$ ) under $\mathrm{CI}$ received the highest attention in the CSR reports, followed by "Access to essential services" $\left(\mathrm{M}_{2013-2016}=75 \%, \mathrm{SD}=0 \%\right)$, "Protecting consumers' health and safety" $\left(\mathrm{M}_{2013-2016}=\right.$ $67 \%, \mathrm{SD}=10 \%)$ and "Sustainable consumption" $\left(\mathrm{M}_{2013-2016}=54 \%, \mathrm{SD}=14 \%\right)$. In contrast, "Consumer data protection and privacy" $\left(\mathrm{M}_{2013-2016}=17 \%, \mathrm{SD}=7 \%\right)$ and "Fair marketing, factual and unbiased information and fair contractual practices" ( $M=15 \%, S D=4 \%$ ) were scarcely reported.

The last theme CID was also valued by companies. Among the subthemes, "Community involvement" $\left(\mathrm{M}_{2013-2016}=100 \%, \mathrm{SD}=0 \%\right)$ received the most attention and was included in the CSR reports of 13 companies from 2013 to 2016, followed by the subthemes of "Education and culture" $\left(\mathrm{M}_{2013-2016}=90 \%, \mathrm{SD}=4 \%\right)$, "Social investment" $\left(\mathrm{M}_{2013-2016}=90 \%, \mathrm{SD}=4 \%\right)$, "Employment creation and skills development" $\left(\mathrm{M}_{2013-2016}=85 \%\right.$, SD = 8\%), "Health" $\left(\mathrm{M}_{2013-2016}=79 \%\right.$, $\left.\mathrm{SD}=5 \%\right)$, and "Wealth and income creation" $\left(\mathrm{M}_{2013-2016}=44 \%, \mathrm{SD}=8 \%\right)$. However, "Technology development and access" $\left(\mathrm{M}_{2013-2016}=6 \%, \mathrm{SD}=8 \%\right)$ was the least reported subtheme.

\subsection{Salient Growth in Reporting on Human Rights and Consumer Issues}

The annual growth rate in Table 4 and Figure 1 shows that a total of 16 issues (DD, RG, DVG, SD, PEBNH, AC, PSR, RPR, FMCP, PCHS, SC, CDPP, TDA, WIC, HE, SI) covered in the reports experienced an increase. The most salient changes occurred in "Consumer data protection and privacy" in CI and "Resolving grievances" in HR. The number of firms that reported "Consumer data protection and privacy" tripled from one to three in four years' time. A similar trend could be observed for "Resolving grievances." In 2013, only three companies focused on "Resolving grievances." Yet, the number of companies doing so doubled in 2014 and rose to seven in 2016. Next, an average growth rate of $10 \%$ to $33 \%$ was noted in "Technology development and access in communities" in CID, "Sustainable consumption" in CI, "Due diligence" in HR, "Protection of the environment, biodiversity and restoration of natural habitats" in EN, and "Anti-corruption" in FOP. Further, "Protecting consumers' health and safety" and "Consumer data protection and privacy" in CI were addressed by two additional firms between 2013 and 2016. 


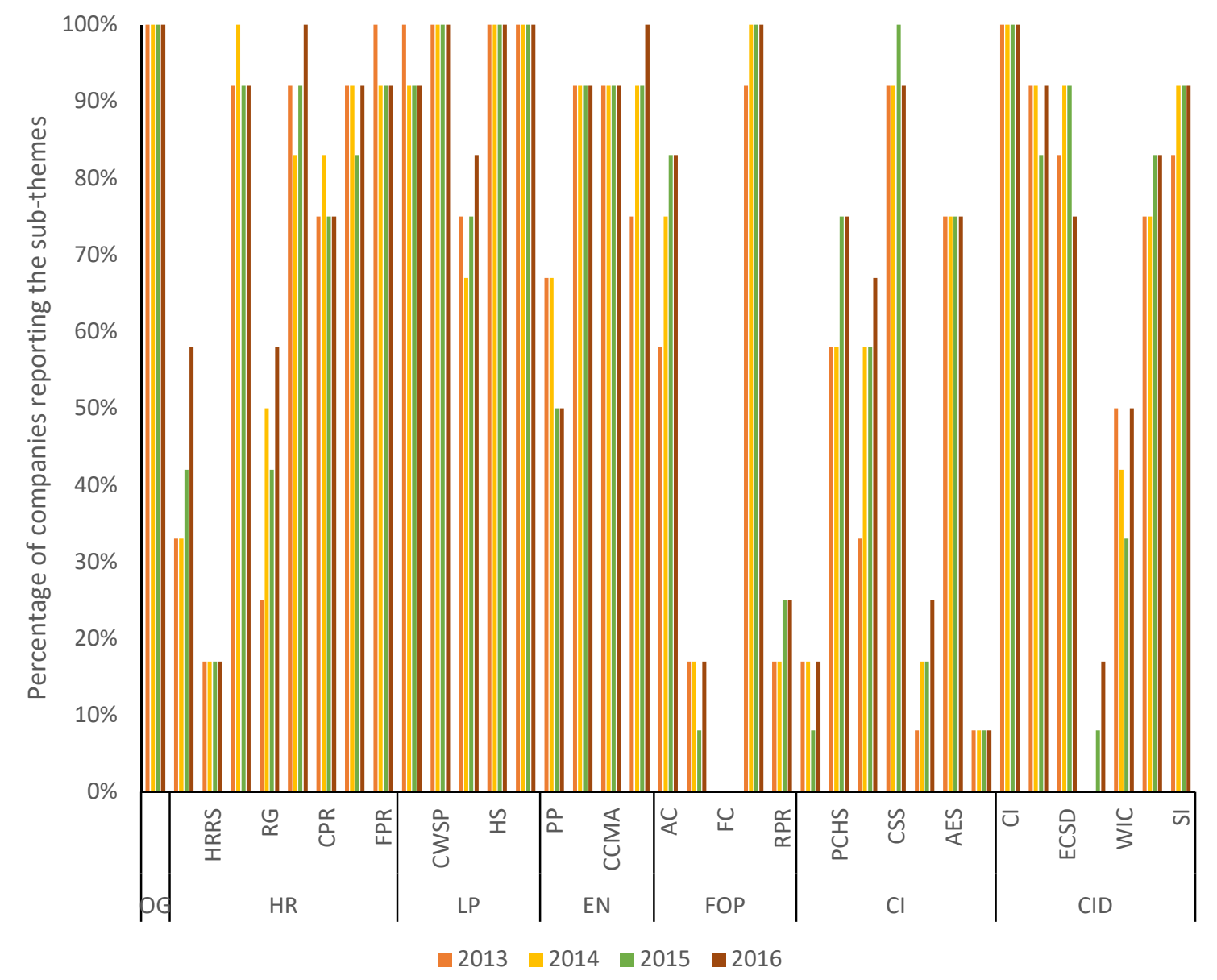

Figure 1. Trends of sustainability reporting in the apparel industry $(\mathrm{N}=12)$.

Although there was a growth witnessed in 16 CSR subthemes, a slight drop was observed in four of the subthemes (FPR, EER, PP, ECSD). For example, eight companies incorporated principles about "Prevention of pollution" (PP) under EN into their sustainability reports in 2013 and 2014. However, the number of reporting companies had dropped to six by 2016.

\subsection{Reporting of Labor Practices in the Fashion Industry}

Regarding RQ2, we examined the key issues of labor practices communicated in the sustainability reports of fashion companies and their changes in practices over time. The most intensively communicated subtheme was "Conditions of work and social protection" $\left(\mathrm{M}_{2013-2016}=36 \%\right.$, SD $=1 \%)$, followed by "Human development and training in the workplace" $\left(\mathrm{M}_{2013-2016}=26 \%\right.$, $\mathrm{SD}=$ $1 \%)$, "Health and safety at work" $\left(\mathrm{M}_{2013-2016}=23 \%, \mathrm{SD}=1 \%\right)$ and "Employment and employment relationships" $\left(\mathrm{M}_{2013-2016}=9 \%, \mathrm{SD}=1 \%\right)$. The least reported issue was "Social dialogue" $\left(\mathrm{M}_{2013-2016}\right.$ $=3 \%, \mathrm{SD}=0 \%$ ).

Figure 2 shows that "Conditions of work and social protection" was the subtheme accounting for the largest proportion in the CSR reports on average from 2013 to 2016. Although it was the most frequently LP issue addressed, it showed a slight drop in 2016 while the second most addressed subtheme of "Human development and training in the workplace" recorded a slight increase from 2013 to 2016. This issue recorded an average growth rate of $8 \%$ between 2013 and 2016 by calculating the growth rate in terms of intensity by year. This suggests a growing tendency of fashion companies to communicate more regarding providing training and career opportunities to employees and suppliers in their sustainability reports. Lastly, the two LP subthemes of "Employment and employment relations" and "Social dialogue" were the least reported. 


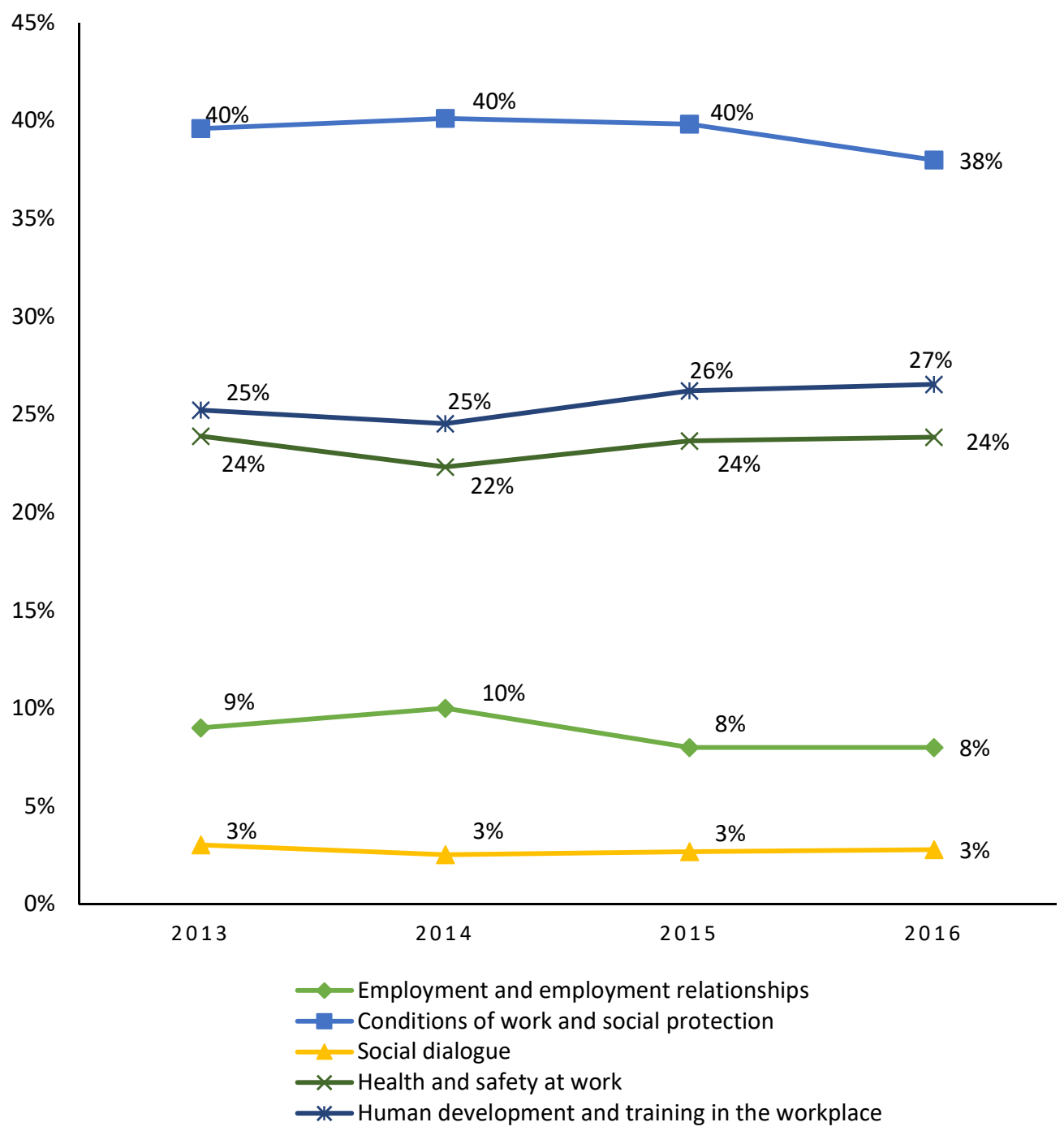

Figure 2. Average intensity of labor issues reflected from the CSR reports per year.

\subsection{Key Issues of Environmental Practices Communicated in the Fashion Industry}

For the key issues of environmental practices communicated in the sustainability reports (RQ3), we found that "Sustainable resource use" was the most frequently communicated subtheme $\left(\mathrm{M}_{2013-2016}\right.$ $=53 \%, \mathrm{SD}=2 \%)$. The sub themes "Climate change mitigation and adaptation" $\left(\mathrm{M}_{2013-2016}=23 \%\right.$, SD $=3 \%)$ and "Protection of biodiversity and natural habitat" $\left(\mathrm{M}_{2013-2016}=18 \%, \mathrm{SD}=4 \%\right)$ ranked second and third respectively. The subtheme "Prevention of pollution" $\left(\mathrm{M}_{2013-2016}=4 \%, \mathrm{SD}=1 \%\right)$ was the least reported.

Descriptive data collected confirmed that "Sustainable resource use" was the most intensely and widely communicated EN subtheme. We found that nine companies (75\%) including company A, C, D, G, H, I, J, K and L focused on reporting "Sustainable resource use," among EN-related subthemes while company $\mathrm{B}$ and $\mathrm{F}(n=2,17 \%)$ focused on "Protection of biodiversity and natural habitat." Only company $\mathrm{E}(n=1,8 \%)$ stressed "Climate change mitigation and adaptation." One aspect that should be noted was that six companies (50\%; D, E, H, I, J and L) reduced their coverage of "Prevention of pollution," while four companies (33\%; A, B, C, and K) never covered this subtheme in their reports.

Figure 3 shows the general trend of the EN-related subthemes addressed by the companies in our sample from 2013 to 2016. It shows that "Sustainable resource use" was the primary issue addressed by companies in their sustainability reports from 2013 to 2016 by calculating the average intensity. Although there was a slight drop from 2014 to 2015, the figure rose in 2016. As for "Climate change 
mitigation and adaptation" and "Protection of the environment, biodiversity and restoration of natural habits", they were the second and third primary issues addressed by companies respectively and the proportion devoted to communicating these two themes in the reports increased and has been maintained at a certain level since 2013. The least reported subtheme of "Prevention of pollution" slightly dropped to 3\% in 2015 and 2016.

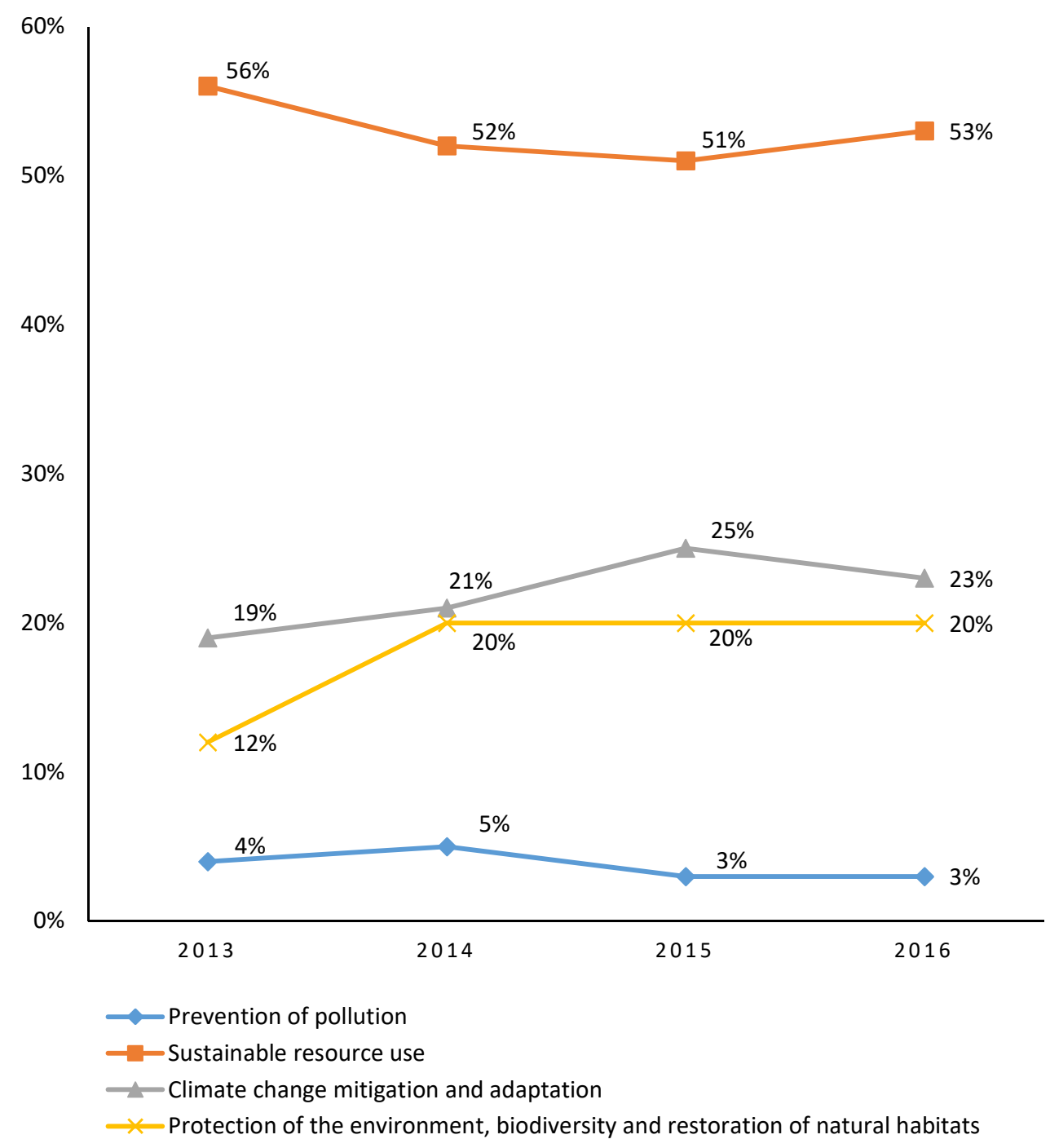

Figure 3. Average intensity of environmental issues reflected from the CSR reports per year.

Through close observation of the data collected over four years, we could see that the fashion companies increased the coverage of "Sustainable resource use", "Climate change mitigation and adaptation" and "Protection of the biodiversity and restoration of natural habitats", but they decreased the coverage of "Prevention of pollution" in sustainability reports. After calculating the average growth rate of each subtheme from 2013 to 2016, the results showed that "Sustainable resource use", "Climate change mitigation and adaptation" and "Protection of the biodiversity and restoration of natural habitats" had a positive growth rate $\left(\mathrm{M}_{\mathrm{SRU}}=18 \%, \mathrm{SD}=107 \% ; \mathrm{M}_{\mathrm{CCMA}}=16 \%\right.$, SD $=45 \%$; $\mathrm{M}_{\mathrm{PEBNH}}=6 \%, \mathrm{SD}=45 \%$ ) while the subtheme of "Prevention of pollution" had a negative growth rate $\left(\mathrm{M}_{\mathrm{PP}}=-14 \%, \mathrm{SD}=69 \%\right)$.

The above analysis indicated a clear shift from a responsive CSR approach to a proactive approach when reporting environmental issues. Instead of discussing how to alleviate the negative environmental impact caused during the product lifecycle, the companies were likely to discuss how to operate their business sustainably. 
Lastly, we examined if the CSR reporting of fashion companies placed more focus on labor issues than environmental issues (RQ4). We employed a two-tailed t-test to compare the intensity level of labor and environmental issues. A significant difference in the intensity of reporting between LP and $\mathrm{EN}\left(\mathrm{M}_{\mathrm{LP}}=18 \%\right.$ vs. $\left.\mathrm{M}_{\mathrm{TE}}=23 \%, \mathrm{t}(93)=-3.25, p=0.002^{* *}\right)$ was observed, meaning that a significantly higher coverage of the environment was found in the CSR reports investigated.

\section{Discussion and Conclusions}

This study involved conducting a longitudinal study of CSR communication in the fashion industry from 2013 to 2016. Different practices and trends in CSR communication were revealed from our analysis of the sustainability reports.

\subsection{Salient Growth in Reporting on Human Rights}

One of the reasons contributing to the salient growth of CSR reporting on human rights-related issues, especially "Resolving grievances" and "Due diligence", was the advocacy of the United Nations Guiding Principle (UNGP) on Business and Human Rights in 2011, highlighting the need for companies to respect human rights and to act with diligence to avoid infringing on the rights of others [45]. After tragedies such as the Rana Plaza incident, there has been increasing pressure from the media, shareholders and NGOs urging the companies to respect human rights and report relevant practices implemented [46]. In response to this global shift, governments and national bodies including the European Union (EU) have also required listed companies to report on human rights- related issues from 2013.

Many global fashion companies have adopted the UN Guiding Principle Reporting Framework launched by Mazars and Shift in 2015 to manage human rights risk and report their human rights practices to their stakeholders [46]. For example, H\&M was one of the first early adopters of the reporting framework to publish information on human rights issues in its 2015 sustainability report [47]. To demonstrate their respect for human rights, corporations need to provide more training on human rights and development and promote greater engagement with workers, communities and suppliers.

\subsection{Greater Emphasis on Human Development and Training in the Workplace}

As stated, companies not only expressed their commitment to providing skills development and career training opportunities to employees but also indicated how to help workers achieve a quality life. Bolton et al. [48] contend that labor issues are gaining more prominence and are highly integrated in the CSR process. For example, activities related to basic skills and training programs for suppliers, vendors, and buying agents were commonly identified in Company A's sustainability reports in 2013, while leadership, advanced skills development training and work-life balance were highlighted in its 2016 report.

Luxury firms, such as company B, G and I, placed emphasis on talent and innovation development. For instance, company G stated the following policy in its 2016 CSR report: "developing talent and skills is at the heart of Kering's human resources policy" and "Kering serves as a catalyst, encouraging them to develop increasingly innovative, appealing and sustainable products." The emphasis on leadership and advanced skills development training as well as work-life balance was preferred by corporations to enhance productivity [49] and improve the retention rate [50]. The rise in productivity and higher rate of retention are mutually beneficial to companies and workers because companies' competitiveness can be strengthened, and workers' and their families' well-being can be improved [51].

\subsection{Focus on Environmental Practices Has Shifted from Prevention of Pollution to Promotion of Sustainable Deeds}

Inconsistent with previous studies, our findings revealed that environmental issues were reported significantly more frequently than labor practices. Our findings are, however, consistent with a recent CSR study of fashion companies' websites [52] which revealed that fashion companies have 
shifted from a reactive approach to a proactive approach when reporting environmental-related issues from 2013 to 2016. Fashion companies tend to focus on promoting sustainable practices instead of preventing pollution in CSR reports. Thus, the coverage of sustainable resource use has increased. For example, in its 2013 report, company J addressed that its business partners must make progressive improvements by integrating principles of sustainability into their business decisions on pollution prevention. The company then elaborated the actions it had taken to tackle the pollution problem. In 2016, company J employed a proactive strategy to express its commitment to environmental protection by advocating the recycling of the whole lifecycle of its products from raw materials to product disposal. A similar shift in CSR strategies and practices was found in the sustainability studies of other industries [53] such as the pharmaceutical [54], manufacturing [55], and food industry [56].

\section{Implications, Further Studies and Limitations}

Our study contributes to the study of CSR communication of the fashion industry in several ways. First, our study is unique as it provides a full picture of how global fashion corporations communicate their CSR practices via sustainability reports. We have revealed the latest CSR trends and changes in the fashion industry by conducting a longitudinal analysis of sustainability reports for four consecutive years following the Rana Plaza incident. Our findings show a salient growth in reporting on human rights, human development and training in the workplace. We have also noticed the shifting of a responsive approach to a proactive approach in terms of environmental issues reporting. These notable changes in CSR reporting have mainly resulted from the increasing scrutiny from the media, stakeholders, NGOs and intergovernmental organizations, as well as the competitive industry environment.

Our findings provide valuable insights into CSR strategies, practices and reporting for the fashion industry. Given the importance of CSR reporting on human rights, human development and training, fashion companies should consider paying more attention to human rights by promoting due diligence to enhance their accountability and transparency. More leadership and advanced skills development training are needed to raise workers' productivity, firms' competitiveness, and the well-being of workers and their communities. In compliance with the changing environmental policies, a proactive CSR strategy and reporting approach are highly recommended for fashion companies operating in EU and other parts of the world.

Despite the contributions, this study has several limitations. First, the small sample size of 12 fashion companies affects the generalizability of the findings although the findings are illuminating. Second, the effectiveness of communication was not investigated because this study focused only on how fashion companies carried out CSR communications. Therefore, future studies could employ survey methods to examine how stakeholders perceive the fashion companies' CSR communication and how the companies could improve their communication to engage stakeholders effectively. Future studies could investigate other garment-related companies, such as discount stores, department stores and garment vendors, to see if any similarities or differences exist in their CSR practices. Studies could also examine the move structure and communication styles of sustainability reports to promote effective writing of sustainability reports in CSR communication.

Author Contributions: Conceptualization, P.F. and C.S.-b.N.; methodology, P.F. and C.S.-b.N.; software, P.F. and C.S.-b.N.; validation, P.F. and C.S.-b.N.; formal analysis, P.F. and C.S.-b.N.; investigation, P.F. and C.S.-b.N.; resources, P.F. and C.S.-b.N.; data curation, P.F.; writing-original draft preparation, P.F.; writing-review and editing, C.S.-b.N.; visualization, P.F. and C.S.-b.N.; supervision, C.S.-b.N.; project administration, P.F. and C.S.-b.N. All authors have read and agreed to the published version of the manuscript.

Funding: This research received no external funding.

Conflicts of Interest: The authors declare no conflict of interest. 


\section{References}

1. Weidstam, E. Sustainability Passion in Fashion: Challenges and Opportunities for Small and Medium-Sized Swedish Apparel Brands when Working with Corporate Social Responsibility in their Global Supply Chain. Available online: https://ieeexplore-ieee-org.ezproxy.lb.polyu.edu.hk/document/5997938/ (accessed on 24 February 2020).

2. Perry, P. Exploring the influence of national cultural context on CSR implementation. J. Fash. Mark. Manag. 2012, 16, 141-160. [CrossRef]

3. Perry, P.; Towers, N. Conceptual framework development. Int. J. Phys. Distrib. Logist. Manag. 2013, 43, 478-501. [CrossRef]

4. Chen, H.-L.; Burns, L.D. Environmental Analysis of Textile Products. Cloth. Text. Res. J. 2006, $24,248-261$. [CrossRef]

5. Kozlowski, A.; Bardecki, M.; Searcy, C. Environmental Impacts in the Fashion Industry: A Life-cycle and Stakeholder Framework. J. Corp. Citizsh. 2012, 45, 17-36.

6. Fletcher, K. Sustainable Fashion and Textiles: Design Journeys, 2nd ed.; Earthscan: London, UK, 2013.

7. Ansett, S. Mind the Gap: A journey to sustainable supply chains. Empl. Responsib. Rights J. 2007, 19, $295-303$. [CrossRef]

8. Economist, T. Bursting at the seams-Bangladesh's Clothing Industry. Available online: https://www. economist.com/leaders/2013/05/04/disaster-at-rana-plaza (accessed on 24 February 2020).

9. Paulina, K. The CSR Challenges in the Clothing Industry. J. Corp. Responsib. Leadersh. 2016, 3, 51-65. [CrossRef]

10. Basil, D.Z.; Erlandson, J. Corporate Social Responsibility website representations: A longitudinal study of internal and external self-presentations. J. Mark. Commun. 2008, 14, 125-137. [CrossRef]

11. Podnar, K. Communicating corporate social responsibility. J. Mark. Commun. 2008, 14, 75-81. [CrossRef]

12. Giau, A.D. Sustainability practices and web-based communication an analysis of the Italian fashion industry. J. Fash. Mark. Manag. 2016, 20, 72-88. [CrossRef]

13. Van Marrewijk, M. Concepts and Definitions of CSR and Corporate Sustainability: Between Agency and Communion. J. Bus. Ethics 2003, 44, 95-105. [CrossRef]

14. Sheehy, B. Defining CSR: Problems and Solutions. J. Bus. Ethics 2015, 131, 625-648. [CrossRef]

15. Elkington, J. Partnerships from Cannibals with Forks: The Triple Bottom Line of 21st-century Business. Environ. Qual. Manag. 1998, 8, 37-51. [CrossRef]

16. Sheehy, B. Corporate Social Responsibility, Sustainability and Corporate Sustainability: What is the difference and does it matter? 2020. Available online: https://papers.ssrn.com/sol3/papers.cfm?abstract_id=3549577 (accessed on 20 March 2020).

17. Christopher, M.; Lowson, R.; Peck, H. Creating agile supply chains in the fashion industry. International J. Retail Distrib. Manag. 2004, 32, 367-376. [CrossRef]

18. Perry, P.; Towers, N. Determining the antecedents for a strategy of corporate social responsibility by smalland medium-sized enterprises in the UK fashion apparel industry. J. Retail. Consum. Serv. 2009, 16, 377-385. [CrossRef]

19. Sodhi, M.S.; Tang, C. Corporate social sustainability in supply chains: A thematic analysis of the literature. Int. J. Prod. Res. 2018, 56, 882-901. [CrossRef]

20. Birtwistle, G.; Moore, C.M. Fashion clothing-Where does it all end up? Int. J. Retail Distrib. Manag. 2007, 35, 210-216. [CrossRef]

21. Dickson, M.A.; Eckman, M. Social Responsibility: The Concept as Defined by Apparel and Textile Scholars. Cloth. Text. Res. J. 2006, 24, 178-191. [CrossRef]

22. Association, N.F. Challenging the Status Quo. Available online: http://nordicfashionassociation.com/news/ challenging-staus-quo/ (accessed on 24 February 2020).

23. Caniato, F.; Caridi, M.; Crippa, L.; Moretto, A. Environmental sustainability in fashion supply chains: An exploratory case based research. Int. J. Prod. Econ. 2011. [CrossRef]

24. Turker, D.; Altuntas, C. Sustainable supply chain management in the fast fashion industry: An analysis of corporate reports. Eur. Manag. J. 2014, 32, 837-849. [CrossRef]

25. Moore, L.L.; De Silva, I.; Hartmann, S. An investigation into the financial return on corporate social responsibility in the apparel industry. J. Corp. Citizsh. 2012, 45, 104-122. [CrossRef] 
26. Nieminen, E.; Linke, M.; Tobler, M.; Beke, B.V. EU COST Action 628: Life cycle assessment (LCA) of textile products, eco-efficiency and definition of best available technology (BAT) of textile processing. J. Clean. Prod. 2007, 15, 1259-1270. [CrossRef]

27. Laudal, T. An Attempt to Determine the CSR Potential of the International Clothing Business. J. Bus. Ethics 2010, 96, 63-77. [CrossRef]

28. Madsen, J.; Hartlin, B.; Perumalpillai, S.; Selby, S.; Aumônier, S. Mapping of evidence on sustainable development impacts that occur in life cycles of clothing. In A Report to the Department for Environment, Food and Rural Affairs; Environmental Resources Management (ERM) Ltd.: London, UK, 2007.

29. Ruwanpura, K. Ethical Codes: Reality and Rhetoric-A Study of Sri Lanka's Apparel Sector. Available online: https://eprints.soton.ac.uk/337113/ (accessed on 24 February 2020).

30. Dirnbach, E. Weaving a Stronger Fabric: Organizing a global sweat-free apparel production agreement. Work. USA 2008, 11, 237-254. [CrossRef]

31. Hearson, M. Cashing in: GIANT Retailers, Purchasing Practices, and Working Conditions in the Garment Industry, Clean Clothes Campaign. Available online: https://digitalcommons.ilr.cornell.edu/cgi/viewcontent. cgi?referer=https://scholar.google.com.hk/\&httpsredir=1\&article=1418\&context=globaldocs (accessed on 24 February 2020).

32. Sheehy, B. TNC Code of Conduct or CSR? A Regulatory Systems Perspective. In Code of Conduct on Transnational Corporations. CSR, Sustainability, Ethics \& Governance; Rahim, M., Ed.; Springer: Cham, Germany, 2020; pp. 45-62.

33. Roberts, S. Supply Chain Specific? Understanding the Patchy Success of Ethical Sourcing Initiatives. J. Bus. Ethics 2003, 44, 159-170. [CrossRef]

34. Weber, M. The business case for corporate social responsibility: A company-level measurement approach for CSR. Eur. Manag. J. 2008, 26, 247-261. [CrossRef]

35. Wildt, S. CSR Communication: A Promotional Tool or a Portrayal of the Reality? An Explorative Study in the Apparel and Footwear Industry. Master's Thesis, University of Boras, Borås, Sweden, 2017.

36. Battisti, M.; Perry, M. Walking the talk? Environmental responsibility from the perspective of small-business owners. Corp. Soc. Responsib. Environ. Manag. 2011, 18, 172. [CrossRef]

37. Moravcikova, K.; Stefanikova, L'.; Rypakova, M. CSR Reporting as an Important Tool of CSR Communication. Procedia Econ. Financ. 2015, 26, 332-338. [CrossRef]

38. Woo, H.; Jin, B. Apparel firms' corporate social responsibility communications. Asia Pac. J. Mark. Logist. 2016, 28, 37-55. [CrossRef]

39. Mann, M.; Byun, S.-E.; Kim, H.; Hoggle, K. Assessment of Leading Apparel Specialty Retailers' CSR Practices as Communicated on Corporate Websites: Problems and Opportunities. J. Bus. Ethics 2014, 122, 599-622. [CrossRef]

40. Gallego, I. The use of economic, social and environmental indicators as a measure of sustainable development in Spain. Corp. Soc. Responsib. Environ. Manag. 2006, 13, 78-97. [CrossRef]

41. Roca, L.C.; Searcy, C. An analysis of indicators disclosed in corporate sustainability reports. J. Clean. Prod. 2012, 20, 103-118. [CrossRef]

42. Tang, L.; Li, H. Corporate social responsibility communication of Chinese and global corporations in China. Public Relat. Rev. 2009, 35, 199-212. [CrossRef]

43. Tsai, S.; Lee, Y.; Wu, C.; Lo, K. A Comparison Study on the Evaluation Criteria for Corporate Social Responsibility. Available online: https:/ieeexplore-ieee-org.ezproxy.lb.polyu.edu.hk/document/5997938/ (accessed on 20 March 2020).

44. ISO 26000 Social Responsibility. Available online: https://www.iso.org/iso-26000-social-responsibility.html (accessed on 20 March 2020).

45. UN Global Compact. Corporate Responsibility Report 2009. Available online: https://www.unglobalcompact. org/participation/report/cop/create-and-submit/detail/6381 (accessed on 17 September 2019).

46. Mazars. Business and Human Rights. Available online: https:/www.mazars.co.uk/Home/Services/ Consulting/People-Processes/Business-and-Human-Rights (accessed on 17 September 2019).

47. UNGP Reporting Framework Website. About Us. Available online: https://www.ungpreporting.org/about-us/ (accessed on 17 September 2019).

48. Bolton, S.; Kim, R.; O'Gorman, K. Corporate social responsibility as a dynamic internal organizational process: A case study. J. Bus. Ethics 2011, 101, 61-74. [CrossRef] 
49. Maitra, P.; Mani, S. Learning and earning: Evidence from a randomized evaluation in India. Labour Econ. 2017, 45, 116-130. [CrossRef]

50. Nanda, P.; Mishra, A.; Walia, S.; Sharma, S.; Weiss, E. Advancing Women, Changing Lives: An Evaluation of Gap Inc.'s P.A.C.E. Program. Available online: https://www.icrw.org/wp-content/uploads/2016/10/PACE_ Report_PRINT_singles_lo.pdf (accessed on 15 September 2019).

51. Skills, C. Employment and Productivity in the Garments and Construction Sectors in Bangladesh and Elsewhere. Available online: https://assets.publishing.service.gov.uk/media/5977616f40f0b649a7000022/ Skills_productivity_and_employment.pdf (accessed on 15 September 2019).

52. Gaskill-Fox, J.; Hyllegard, K.H.; Ogle, J.P. CSR reporting on apparel companies' websites: Framing good deeds and clarifying missteps. Fash. Text. 2014, 1, 11. [CrossRef]

53. Hahn, R.; Kühnen, M. Determinants of sustainability reporting: A review of results, trends, theory, and opportunities in an expanding field of research. J. Clean. Prod. 2013, 5, 5-21. [CrossRef]

54. Nussbaum, A.K. Ethical corporate social responsibility (CSR) and the pharmaceutical industry: A happy couple. J. Med. Mark. 2009, 9, 67-76. [CrossRef]

55. Torugsa, N.A.; O'Donohue, W.; Rob, H. Capabilities, proactive CSR and financial performance in SMEs: Empirical evidence from an Australian manufacturing industry sector. J. Bus. Ethics 2012, 109, 483-500. [CrossRef]

56. Lamberti, L.; Lettieri, E. CSR practices and corporate strategy: Evidence from a longitudinal case study. J. Bus. Ethics 2009, 87, 153-168. [CrossRef]

(C) 2020 by the authors. Licensee MDPI, Basel, Switzerland. This article is an open access article distributed under the terms and conditions of the Creative Commons Attribution (CC BY) license (http://creativecommons.org/licenses/by/4.0/). 